\title{
Ledelse af frivillige - når regler og værdier brydes
}

\section{LEDELSE • FORMALISERET SAMARBEJDE • SAMSKABELSE VAERDIER • REGLER • KOLLEKTIV LAERING}




\section{Ledelse af frivillige - når regler og værdier brydes}

\section{LEDELSE • FORMALISERET SAMARBEJDE • SAMSKABELSE VAERDIER • REGLER • KOLLEKTIV LAERING}

En vigtig del af offentlig ledelse er i dag at organisere samarbejdet med frivillige.

Særligt har det offentlige fået øje på, at inddragelsen af frivillige kan udgøre et vigtigt bidrag til kommunernes udvikling af velfærden. Kommunerne står derfor i dag over for den udfordring, at finde frem til den bedste måde at organisere samarbejdet mellem de frivillige og kommunens ansatte.

Artiklens hovedpointe er, at i bestræbelserne på at finde den rette form for samarbejde med de frivillige er det vigtigt, at ledelsen har blik for de modsætninger, der eksisterer mellem regler og værdier, og som altid har præget forsøg på at organisere den frivillige indsats. I stedet for at ignorere de mange modsætninger, der kan opstå mellem regler og værdier, skal ledelsen derfor tage ansvar for at skabe et kollektivt læringsmiljø, der kan øge organisationens evne til at reagere og håndtere komplekse situationer, hvor regler og værdier ikke nødvendigvis spiller sammen. 


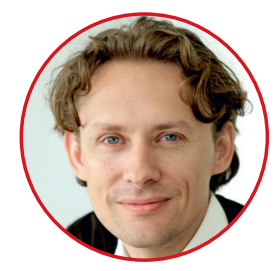

Anders La Cour

Anders la Cour har en $\mathrm{PhD}$ i sociologi fra Københavns Universitet, og arbejder i dag som lektor på intstitut for Ledelse, Politik \& Filosofi, CBS.

Anders har i mange år forsket i de særlige betingelser der gælder for ledelse af frivillige. Han har publiceret en lang række artikler om emnet i såvel danske som internationale tidsskrifter, og er en flittigt benyttet foredragsholder. 
I sommeren 2018 blev jeg venligt, men bestemt, ført ud af den frivillige organisations Big Brother Big Sisters (BBBS) hovedsæde i Chicago. Det tog mig noget tid, før jeg forstod, hvorfor det ellers så venlige og imødekommende personale havde valgt at afbryde vores møde før tid. Et par måneder forinden havde jeg kontaktet ledelsen via mail. Jeg havde præsenteret mig som mangeårig forsker i ledelse af frivillige på Copenhagen Business School, og de sidste par år havde jeg beskæftiget mig særligt med deres organisation. Jeg håbede, at modtageren af mailen ville blive nysgerrig på mit arbejde og takke ja til at mødes med mig for at udveksle erfaringer om de mange udfordringer, som følger med, når man forsøger at lede frivillige. Det havde da også smigret min forfængelighed, da de kort tid efter accepterede mit tilbud.

Big Brother Big Sister er trods alt ikke en hvilken som helst frivillig organisation. Med 300 afdelinger og over 400.000 frivillige alene i USA hører organisationen til en af verdens største frivillige organisationer målt på antal frivillige. Deres mission er at give børn, der vokser op i fattigdom, og hvor en af forældrene ofte er i fængsel, en voksen, som de kan se op til og bruge som rollemodel. Derfor matcher BBBS voksne frivillige, som de kalder "bigs", med børn under 12 år ("littles"), for at de sammen kan udvikle et forhold, der kan styrke barnets muligheder for at tage en uddannelse og komme ud af den fattigdom, som de kommer fra. BBBS skriver på deres hjemmeside, at de i løbet af de sidste 10 år har hjulpet mere end 2 millioner børn.

Jeg har gennem mange år beskæftiget mig med frivillige organisationer, hvoraf flere i deres værdigrundlag og målsætninger minder om BBBS, men alene forskellen i størrelse gjorde BBBS til en interessant organisation at studere nærmere. I flyet havde jeg siddet og varmet mig ved tanken om, hvordan jeg skulle præsentere mine tanker om ledelse og måske endda være med til at udvikle organisationens arbejde med deres ledelsesstrategier. Sådan skulle det ikke gå - langt fra endda. Men lad mig først beskrive, hvorfor BBBS, ud over dens størrelse, havde vækket min interesse. Det skyldtes først og fremmest, at jeg via mine besøg og interviews af deres mellemledere gennem en årrække var blevet imponeret over deres effektive og engagerede ledelsesform.

I BBBS er der en konstant nærværende ledelse, der aldrig slipper de frivillige, børnene eller deres forældre af syne, og som hele tiden står parat til at hjælpe, hvis relationerne ikke fungerer som ønsket. Det sidste er ofte tilfældet, for det er ikke nogen nem sag at bringe velhavende og velfungerende voksne fra den højere (ofte hvide) middelklasse sammen med børn under 12 år fra fattige (ofte afroamerikanske) familier.

Et sådant møde kan have svært ved at leve op til de store forventninger om intimitet og nærvær. De mange ansatte ledere har derfor travlt med at få relationen til at overleve de ofte indledende skuffelser og vanskeligheder, så relationen kan nå at vokse sig stærk og med tiden indfri de mange forventninger, som den voksne har til at "gøre en forskel" (her og nu), og som barnet (og ikke mindst moderen) har til, at dette endelig ville blive set og elsket (og helst med det samme).

Selvom jeg beundrede den ildhu, som de mange ansatte lagde i deres arbejde, tænkte jeg også, at organisationen havde nogle udfordringer. Når jeg var imponeret af det arbejde, der blev udført, skyldtes det blandt andet, at jeg var blevet opmærksom på, hvorledes både de ansatte og de frivillige måtte manøvrere mellem organisationens regler og værdier. På den ene side var det tydeligt, at organisationens værdier hvilede på ønsket om, at "the big" skulle være som den storebror eller storesøster, som manglede i "the little's" liv. En som kunne være der for "the little", og som denne kunne se op til som en vigtig rollemodel. Organisationens værdier 
byggede med andre ord på en forestilling om autenticitet, da man håbede, at relationen kunne udvikle sig til noget eksklusivt, noget enestående, og at den voksne over tid kunne udvikle sig til at være netop den storebror eller storesøster, der manglede i barnets liv.

BBBS hvilede således på nogle stærke værdier, som den havde stor succes med at gøre til et fælles anliggende for både de ansatte, frivillige og deres brugere. At disse værdier levede i organisationen, havde jeg ved selvsyn observeret gennem flere interviews med de ansatte og de frivillige. De tog alle udgangspunkt i værdierne, når de skulle vurdere, hvem der skulle matches med hvem, eller hvornår det var nødvendigt at gribe ind over for relationer, der ikke levede op til organisationens værdier og målsætninger om at skabe "autentiske relationer" til gavn for begge parter.

Men samtidig med det stærke værdigrundlag har BBBS også formuleret en række regler, som de ansatte, de frivillige og brugerne skal leve op til. For eksempel skal alle "bigs" og pårørende til "the littles" underskrive en kontrakt, hvor de blandt andet forpligter sig på, at "the bigs" og deres "littles" ikke mødes oftere end to gange om måneden. De må heller ikke mødes privat, hverken hos "the big" eller dennes venner eller familie, men skal begrænse deres møder til offentlige steder. Eventuelle gaver skal på forhånd vendes med organisationen og må ikke overstige 25 dollars. Og samtidig skal "the bigs" og deres "littles" undgå at lave risikable ting som springe i elastik, ro i kajak eller køre gokart sammen.

Der er forskellige grunde til de forskellige regler. Blandt andet er BBBS opmærksom på, at selvom man gerne vil have, at barnet knytter sig til den voksne, må barnet heller ikke blive for afhængigt af denne. Organisationen vurderer, at det vil være usundt for barnets udvikling, hvis den voksne får en for dominerende plads i dennes liv. Ligeledes er det vigtigt, at organisationen minimerer risikoen for, at barnet på den ene eller den anden måde bliver misbrugt af den voksne. Derfor bliver det indskærpet, at de ikke må være alene med hinanden, men altid skal færdes på offentlige steder. Der er samtidig et spørgsmål om forsikring, som nødvendiggør, at aktiviteterne ikke bliver vurderede som farlige og risikofyldte for barnets sundhed. Med andre ord er der en række regler, som er nødvendige for "at holde snor i relationen", som en af lederne udtalte, så samme relation ikke risikerer at udvikle sig til noget, der ikke er hensigtsmæssigt. Organisationen understregede flere gange, hvor stort et ansvar den havde for, at de flere tusinde relationer ikke udviklede sig til noget, der var til skade for barnet. Reglerne var et resultat af de mange års erfaringer, som BBBS har gjort sig i forhold til bedst at minimere denne risiko.

Regler og værdier er således vigtige, for at forstå hvilke særlige betingelser, der gælder for ledelse af frivillige, i BBBS, som i enhver anden organisation. Lad os derfor se lidt nærmere på, hvad der egentlig skal forstås ved regler og værdier.

\section{Regler og værdier}

Regler er til for at skabe klarhed. For eksempel om, hvem der er medlem af en organisation, og hvad deres rolle er. Regler fungerer også som klare forskrifter for den rigtige adfærd. Deres styrke ligger i, at de foreskriver, hvad der kan forventes, og samtidig gør det muligt at iagttage, hvornår de bliver overholdt, og hvornår de bliver brudt. Organisationer ville ikke kunne skabe entydighed og sikkerhed uden regler. Når man træder i en organisation, ved man med andre 
ord, hvad der forventes af en, og hvad man kan forvente af andre, fordi der er regler, der regulerer, hvad man skal, hvornår og hvordan (Luhmann, 2000a, s. 183; Thyssen, 2000, s. 40). Fordelen ved regler er, at man ikke behøver at have et indgående kendskab til sine kollegaer for at vide, hvad der nu skal ske. Strengt formelle organisationer kan som et andet trafiklys regulere adfærden, fordi alle har kendskab til reglerne for rødt, gult og grønt. Regler skaber med andre ord en klar struktur.

Værdier handler derimod om, hvilke idealer man har for, hvad der er rigtigt og forkert, det man efterstræber og vil arbejde for. Det kan være værdier om solidaritet, tryghed, ansvar eller personlig frihed. Mens regler formulerer klare forventninger til adfærd, så er værdier mere tvetydige og kræver en udlægning. Den amerikanske sociolog Shalom Schwarts definerer værdier som de kriterier, mennesker bruger til at vurdere andres og egne handlinger med (Schwartz, 1992, s. 1). Værdier kan fungere som pejlemærker i situationer, hvor det er svært at opsætte tydeligt definerede regler, alene af den grund, at det er umuligt at formulere regler for alting, men også fordi værdier tilbyder en orientering, som ikke lader sig binde af regler. Hvis værdier fungerer i praksis, hjælper de ledelsen til at vurdere, om en given handling eller situation repræsenterer det, som organisationen finder ønskeligt og gerne vil opnå (Luhmann, 2000a, s. 372).

Forskellen mellem regler og værdier er, at mens regler repræsenterer forskrifter for, hvad for eksempel de frivillige må og ikke må, og som kan nedfældes i manualer eller kontrakter, så er værdier generelle beskrivelser af, hvad man gerne vil opnå, og samtidig er værdier åbne for fortolkning. Værdier repræsenterer derfor ikke lange lister om, hvem der skal gøre hvad og hvornår, men fungerer derimod som generelle beskrivelser af, hvad man opfatter som en ønskværdig måde at handle på. Værdier, der på forhånd konkretiserer, hvordan de skal udmøntes i konkrete handlinger, ville være værdier, der er degeneret til blot at udgøre regler, som Ole Thyssen formulerer det (Thyssen, 2007, s. 239).

Spørgsmålet om værdier kommer ofte i spil, når der opstår situationer, som reglerne ikke har forudset, eller fordi reglerne for overtrædelse af regler er uklare. Med andre ord kan man jo altid spørge ind til, hvor strengt en regel skal overholdes? Skal bussen køre præcist som timeplanen foreskriver? Ja, kunne man svare, hvis værdien af at være punktlig er afgørende. Men hvis buschaufføren kan se i sit bakspejl, at en passager er forsinket og kommer løbende, skal man så alligevel vente og tage vedkommende op - også selvom det så går ud over punktligheden? Det kommer jo an på, om værdier som hensynsfuldhed og fleksibilitet også trænger sig på.

I tilfælde, hvor en overtrædelse af en regel ikke er harmløs, tålelig eller ligefrem tilrådelig, og hvor spørgsmålet om overholdelse ikke skal overlades til en diffus og individuel moralsk vurdering, er det op til organisationen at formulere, hvilke værdier organisationens medlemmer forventes at følge. Skal chaufføren køre eller vente i den konkrete situation? Her kan værdier, der løfter sig over den konkrete situation, være en vigtig rettesnor for, hvad man som organisation efterstræber og finder ønskværdigt. 


\section{BBBS og dens værdier og regler}

Både værdier og regler spiller en vigtig rolle i BBBS' arbejde med frivillige. Hverken regler eller værdier kan undværes, for uden værdier ville man ikke vide, hvad man som organisation stræbte efter, og uden regler ville der ikke være en afklaring af, hvordan man skulle opnå organisations målsætninger. Det er derfor indlysende, at regler og værdier gerne skulle arbejde sammen, således at reglerne understøtter organisationens værdier og målsætninger, som i BBBS' tilfælde handler om at skabe "autentiske" relationer mellem organisationens frivillige og de udsatte børn. Men lige præcis her var BBBS udfordret. Dens regler understøttede ikke altid dens værdier. For hvordan skal man nå målet om at skabe "autentiske" relationer, når de samme relationer var pakket ind i regler om, hvor tit de måtte mødes, hvor de måtte mødes, og hvad de måtte mødes om? Et af de steder, hvor modsætningerne tydeligst kommer til udtryk, er i BBBS' egne videoer, som de producerer for at gøre opmærksom på deres arbejde. I disse videoer kan man se "bigs" og "littles" enten hver for sig eller sammen, fortælle om deres relationer. Det påfaldende i disse videoer er, at de alle fungerer som eksempler på, hvorledes netop deres relation opleves som unik, og hvordan forholdet har udviklet sig eksklusivt på dets egne betingelser, og hvordan "the big" er blevet som en storebror eller storesøster for "the little". Det er således videoer, som organisationen har valgt at lægge op på deres hjemmesider, fordi de alle repræsenterer succesfulde eksempler på, at organisationen lever op til sine værdier om at skabe autentiske og unikke relationer mellem voksne og børn fra ellers meget forskellige miljøer.

Men videoerne viser også, at mange af relationerne bryder med organisationens regler. Der er således eksempler på, hvordan "the little" ofte kommer hjem hos "the big", hvordan de laver mad sammen, går i swimmingpool og nogle gange overnatter "the little" hjemme hos "the big". I videoerne fremstår disse overtrædelser som noget helt naturligt, fordi barnet og den voksne har udviklet en helt særlig og privat relation til hinanden. For mig var videoerne et godt eksempel på, hvordan en organisation nogle gange er nødt til at acceptere brud på egne regler for at kunne leve op til egne værdier og målsætninger. De mange relationer fremstod på videoerne som "autentiske" og "eksklusive", netop fordi de ikke synes at være styret af regler, men af de indbyrdes relationer.

Dette var så indlysende, at jeg ikke havde tænkt, at dette i sig selv kunne være kontroversielt. Alle og enhver kunne jo gå ind og downloade deres regler og se deres videoer og med egne øjne se, at mange af de præsenterede relationer overskred organisationens regler. Min egentlig pointe, den som jeg ville frem til i mit oplæg, var, at der hverken var noget galt med organisationens regler eller værdier, både regler og værdier var vigtige, men at det samtidig satte deres mellemledere i nogle svære situationer, fordi de skulle navigere mellem organisationens regler og værdier uden klare retningslinjer for, hvordan det skulle gøres. Når "the bigs" så "the little" oftere end to gange om måneden, når "the bigs" ringede oftere end planlagt, når "the bigs" inviterede "the little" hjem til sig, var det så et udtryk for, at forholdet var ved at indløse organisationens værdier om autenticitet, eller var det et udtryk for, at der var noget galt? Noget som der skulle gribes ind overfor? Her var der ingen manual for lederne at støtte sig til.

I mit oplæg lagde jeg således vægt på, at ledelse handler om meget mere end blot at følge organisationens regler. Tværtimod havde jeg mødt ledere, der var tvunget til at improvisere mellem BBBS' regler og værdier for at få enderne til at mødes. Jeg dristede mig endda til at 
citere den franske sociolog Pierre Bourdieu og hans påpegning af, at ledelse netop er lig med kunsten af at improvisere (Mowles et al., 2008). Og jeg roste organisationens mellemledere for deres store kreativitet i dette arbejde. Det var stort set alle ledere, der havde indset, at ikke alle beslutninger kan henholde sig til regler, men at selve det at overskride reglerne kan være præcist det, der gør, at man kommer tættere på at indløse organisationens værdier. Men, igen, at dette jo aldrig altid var tilfældet. Nogle gange var reglerne vigtige at henholde sig til, så organisationen kunne beskytte børnene. Min slutpointe var, at i stedet for at ignorere, at dens mellemledere ofte befandt sig i situationer, hvor de måtte ignorere reglerne for at leve op til værdierne, måtte organisationen tage denne viden til sig og reflektere over, hvordan den kunne understøtte mellemledernes evne til at navigere i en modsætningsfyldt hverdag af regler og værdier.

Men før vi vender tilbage til, hvorfor topledelsen i BBBS Chicago tog mit oplæg så ilde op, vil jeg vende tilbage til Danmark for en kort stund. Vi behøver nemlig ikke at flyve helt over Atlanten for at iagttage, hvordan regler og værdier giver anledning til udfordringer, når det gælder ledelse af frivillige. Det skyldes, at frivilligheden ofte bliver anset som et alternativ til den professionelle indsats' orientering efter regler og metoder. Frivillige hyldes, fordi de møder andre mennesker der, hvor de er, og at de netop kan nå dem, fordi de ikke lader sig styre af regler, men derimod lader sig styre af, hvad den umiddelbare situation synes at kræve. Værdierne, der beskriver den ideelle frivillige, er således allerede i konflikt med de regler, som enhver organisation forsøger at sætte op, fordi organisationen samtidig gerne vil give den frivillige indsats en bestemt retning og kvalitet (se også la Cour, 2019).

\author{
Spændingen mellem regler og værdier gør sig ikke kun gældende for ledere \\ i den frivillige sektor. I takt med at kommunerne i stigende udstrækning \\ inviterer frivillige indenfor som et vigtigt bidrag til udviklingen af deres \\ velfærdsydelser, udfordres også offentlige ledere af at skulle navigere \\ mellem hensynet til værdier og behovet for regler. Offentlige ledere synes at \\ stå over for en tosidet udfordring. Ikke alene skal de finde en løsning på at \\ navigere mellem regler og værdier i deres organisering af den frivillige \\ indsats, de skal samtidig sørge for, at dette sker i et frugtbart samspil med \\ de offentligt ansatte.
}

I det følgende vil jeg skitsere, hvorledes der har udviklet sig to forskellige retninger i forhold til, hvordan samarbejdet mellem det offentlige og de frivillige skal organiseres. De to retninger repræsenterer først og fremmest to forskellige opfattelser af, hvordan forholdet mellem værdier og regler skal håndteres.

\title{
Offentligt og frivilligt samarbejde - men hvordan?
}

En afgørende del af offentlig ledelse i dag er en stræben efter at samarbejde med frivillige om at udvikle og producere velfærd. I en tid med begrænsede ressourcer og øgede forventninger er samarbejde blevet nøglen til at udnytte lokal samfundets ressourcer mere effektivt og løse komplicerede sociale udfordringer. Der er med andre ord store forventninger til, hvad et tættere samarbejde mellem kommuner og frivillige kan bidrage med i forhold til at øge kvaliteten af den kommunale velfærd. Derfor ser vi også, at flere og flere velfærdsydelser bliver til som et resultat 
af et samarbejde mellem professionelle og frivillige (Hjære \& Jørgensen, 2017).

Samtidig med, at Social- og Indenrigsministeriet lægger op til, at kommunerne skal udvikle en mere eksperimenterende og undersøgende tilgang til, hvordan et effektiv samarbejde kan etableres mellem det offentlige og den frivillige verden, anbefaler ministeriet at "samspillet mellem kommunalbestyrelsen og frivillige sociale organisationer og foreninger bygger på de principper, der er nedfældet $\mathrm{i}$ »Charter for samspil mellem den frivillige verden og det offentlige« (Social- og Indenrigsministeriet 2020). I chartret kan man læse, at en fortsat udvikling af det danske samfund, er afhængigt af et konstruktivt og dynamisk samspil mellem den frivillige verden og det offentlige. Derfor understreger chartret, at det offentlige "bør" inddrage den frivillige verden "i alle relevante spørgsmål og sammenhænge" (Frivilligheds chartret, 2013, s. 2). Når det gælder selve organiseringen af samspillet, synes chartret at være splittet. På den ene side understreger det vigtigheden af, at den frivillige verden og det offentlige kan udfordre og skabe hinandens roller, og at frivilligheden får så vide rammer som muligt for at udfolde sig (Frivillighed chartret 2013, s. 4). Her understreger chartret værdien af de frivilliges autonomi og alternative måde at udøve deres sociale indsats på. På den anden side fremhæver chartret vigtigheden af, at der foregår en klar forventningsafstemning, hvor de frivilliges opgaver fremstår forståelige og konkrete. Det skal derfor aftales lokalt "Hvem der gør hvad, så det enkelte samspil baseres på lokale ønsker, behov og fælles spilleregler, herunder på samarbejdet mellem de frivillige og de offentlige ansatte (Frivilligheds chartret 2013, s. 3). Der synes således at være en dobbelthed på spil i chartret, hvor nødvendigheden af klare aftaler, roller og opgaver understreges, samtidig med at chartret opfordrer til, at de frivillige gives vide rammer for deres indsats, så det kan udfordre det offentliges traditionelle roller.

Netop fordi chartret ikke give nogle klare retningslinjer for samarbejdet mellem den frivillige verden og det offentlige, og for hvordan forskellen mellem værdier og regler skal håndteres, er det interessant at iagttage, hvordan de toneangivende aktører vælger at udlægge chartret. En af disse aktører er Center for Frivilligt Socialt Arbejde (CFSA), der er et landsdækkende støtteog udviklingscenter, som er finansieret af staten, og som har til formål at styrke og udvikle den frivillige sociale indsats i Danmark.

Med udgangspunkt i det nationale charter udbyder centret kurser i, hvordan man skaber de bedste rammer for samarbejdet mellem den frivillige verden og det offentlige. I forbindelse med disse kurser udgiver centret guider til, hvordan kommuner gennem skriftlige aftaler kan udforme grundige forventningsafstemninger, der skal sikre en klar rollefordeling mellem kommunens ansatte og de frivillige. F.eks. står der i centrets guide for det gode samarbejde, at det er vigtigt, at parterne i fælleskab udfærdiger en skriftlig samarbejdsaftale, hvor alle aktørers roller og opgaver er beskrevet. Her understreges det blandt andet, at det er særligt vigtigt, at aftalerne beskriver, hvor grænsen for de frivilliges opgaver går (Center for Frivilligt Socialt Arbejde, 2020).

Kommunernes Landsforening understreger ligeledes, at god ledelse af samarbejdet mellem det offentlige og de frivillige handler om, at ledelsen på forhånd formulerer en række klare rollefordelinger mellem de professionelle og de frivillige, så man på forhånd ved, hvor de offentlige medarbejderes opgaver adskiller sig fra de frivilliges (Ziegler \& Adelskov, 2019). Det gode samarbejde "kræver en grundig forventningsafstemning, hvor formål og målgruppe samt rolle fordeling for samarbejdet afklares" (Ziegler \& Adelskov, 2019, s. 78). Fagforeningen FOA følger trop, når deres forbundsformand Mona Striib påpeger, at god ledelse af samarbejdet 
handler om at formulere konkrete aftaler mellem de ansatte og de frivillige, så der er klare retningslinjer for, hvilke opgaver de frivillige skal løse, og hvilke de ikke skal: "FOA mener, at der er helt afgørende at ledelsen og tillidsrepræsentanterne på de offentlige arbejdspladser sætter sig rundt om det samme bord og aftaler, hvordan samarbejdet med frivillige skal være lige præcis hos os. Og aftalerne skal være så konkrete, at den enkelte medarbejder ikke skal bruge sin knappe tid på usynligt arbejde med at lede og fordele arbejde blandt de frivillige og løse konflikter om, hvordan det faglige arbejde skal løses." (Striib, 2019, s. 81). Samtidig understreger begge organisationer, at man skal respektere de frivilliges særlige værdi og de præmisser, de udøver deres frivillighed på (Ziegler \& Adelskov, 2019; Striib, 2019).

Den dobbelthed, der præger det nationale frivillighedscharter, vægtning af både værdier og regler, synes at være forsvundet i CSFA, KL og FOA's politik på området. Selvom de frivilliges særlige værdier hyldes, lægges der ikke skjul på, at forudsætningen for det gode samarbejde er formuleringer af regler for, hvordan de forskellige aktører, professionelle som frivillige, skal indgå i dette samarbejde. Der synes således at være bred enighed om, at det gode samarbejde hviler på aktørernes evne til på forhånd at aftale klare rollefordelinger mellem de professionelle og de frivilliges opgaver. Vender man blikket mod den internationale forskning, kan man iagttage, hvordan dele af den bakker op om vigtigheden af, at formulere klare aftaler om, hvem der gør hvad. Her påpeges det blandt andet, at netop manglen på klare forventninger og entydig rollefordeling mellem professionelle og frivillige ofte skaber forvirring og konflikter mellem de to grupper (Blix \& Hamran, 2017; Skinner et al., 2020). Derfor anbefales det også her, at der på forhånd formuleres klare beskrivelser af de forskellige aktørers roller, så det klart fremgår, hvilke opgaver der er reserveret til de professionelle. Herved undgår man, at de professionelle føler sig udfordrede på deres fags autoritet og privilegier, og at de frivillige bliver presset til at udføre opgaver, som de ikke er klædt på til, hvorfor man risikerer, at de mister motivation og engagement. Flere studier viser da også, at samarbejdsprojekter med frivillige ofte bliver set som en trussel mod de professionelles roller og privilegerede status (van Bochove et al., 2018; Merrell, 2000). Grænser er her vigtige, fordi de markerer, hvilke velfærdsområder der kræver specialiseret viden og legitimerer ulige magtforhold. Der synes således at være bred enighed om, at konkrete og klare aftaler, der kan skabe orden og stabile rammer, er en forudsætning for det gode samarbejde.

Nyere forskning peger imidlertid på, at mens der nok er klare grænser på nogle velfærdsområder, så eksisterer der også mange gråzoner, hvor det forbliver uklart, hvilke opgaver en frivillig kan påtage sig, og hvilke hun ikke kan (Verhoeven \& Bochove, 2018; van Bochove et al., 2018; Overgaard 2015, 2019). I disse gråzoner opererer de professionelle og de frivillige i realiteten uden klare regler, hvorfor de hele tiden forhandler grænser og overskrider dem i deres konkrete samarbejde (Skinner et al, 2020; Overgaard, 2015). Allerede tidligt gjorde en gren af forskningen opmærksom på, at grænserne mellem de professionelle og de frivilliges roller i praksis ikke er noget, der kan fastlægges via en overordnet politik for samarbejdet, men at grænserne derimod er flydende og konstant til forhandling (Henriksen, 1996). Politisk fastsatte præmisser bliver således erstattet af hverdagens intensitet. Ledelse af samarbejde kan derfor ikke blot forstås som et spørgsmål om at implementere politiske beslutninger i forskellige lokale kontekster. I stedet skubbes spørgsmålet om grænser ud til de lokale aktører, der til gengæld forventes at udvikle en eksperimenterede tilgang til, hvordan samarbejdet kan finde sin konkrete form. Det kan med andre ord ikke forudsiges hvad samarbejdet kommer til at handle om, og hvad de konkrete velfærdsydelser kommer til at bestå af (Henriksen, 1996; la Cour, 2014). 


\section{Denne del af forskningen går således i rette med forestillingen om, at samarbej- det mellem den frivillige verden og det offentlige kan fastlægges på forhånd gennem konkrete regler og gensidige forventningsafstemninger. Den interna- tionale forskning er således i lighed med det nationale frivilligheds charter splittet i forhold til, om samarbejdet skal struktureres via regler om klarhed i rollevaretagelsen, eller om frivillighedens autonomi skal udgøre værdigrundla- get for samarbejdet.}

På den baggrund er det bemærkelsesværdigt at en række danske kommuner, f.eks. Skanderborg (Kommune 3.0), Aarhus (Kommune forfra), Holbæk (Holbæk i fællesskab) og Ringkøbing-Skjern, på en række punkter har valgt at gå stik imod de forestillinger om det formaliserede samarbejde som CSFA, FOA og KL plæderer for. En af de kommuner, der er gået længst i denne udvikling, er Ringkøbing-Skjern, der har iværksat tre samarbejdsprojekter i deres ældrecentre, deres folkeskoler og i deres parker. Med involveringen af frivillige ønsker kommunen at eksperimentere med, hvad frivillige kan bidrage med og samtidig udfordre de givne strukturer. Derfor er det ikke på forhånd aftalt, hvad de frivillige skal bidrage med. I stedet forsøger kommunen at udvise respekt for frivillighedens autonomi som en vigtig værdi for samarbejdet ved at skabe et rum, hvor de frivillige, sammen med de professionelle kan undersøge, hvordan deres samarbejde kan tage form.

Kommunen er derfor opmærksom på netop ikke på forhånd at formulere forventninger til samarbejdets form og indhold. I stedet prøver man at fremme en undersøgende tilgang til, hvad samarbejdet kan være et samarbejde om. Selvom der på kommunens hjemmeside er nedskrevet nogle generelle retningslinjer for kommunens samarbejde med de frivillige, forventer kommunen, at det først og fremmest er på hverdagens præmisser, at samarbejdet finder sin konkrete form. Det betyder, at ledelsen forsøger at lægge det så åbent ud som muligt, hvad de frivillige og de professionelle skal samarbejde om. Det betyder til gengæld også, at kommunen accepterer, at det kan give anledning til nye udfordringer, når de frivilliges værdi af at udvikle sig på sine egne præmisser, bliver givet plads. Når de frivillige underviser uden at overholde tiden; når skraldespandene i parken ikke bliver tømt; når frivillige hjælper med flytning, men gør det på en ukoordineret måde; når der pludselig bygges et legehus på legepladsen, som ikke var planlagt, og som måske ikke lever op til beskrevne sikkerhedsforanstaltninger, så skaber det nye udfordringer, som kommunen ikke før har oplevet. Ringkøbing Kommune synes ikke at tage disse udfordringer særlig tungt. Tværtimod udviser kommunen en overraskende evne til at komme videre og $\mathrm{i}$ stedet skabe grobund for, at nye aktiviteter hele tiden kan blive til og være med til at udfordre den traditionelle måde at gøre tingene på (for en mere udfoldet beskrivelse af Ringkøbing-Skjerns Kommunes samarbejde med frivillige, se Lauritzen, 2019).

I Ringkøbing-Skjern bliver den stabile struktur i kommunens offentlige velfærdsindsats set som noget, der står i vejen for den nødvendige udvikling af velfærdsindsatsen. I stedet prøver man at gøre op med regler og strukturer i forsøget på at udvikle velfærden. Frivillighedens autonome karakter udgør her en vigtig værdi, fordi den bidrager til den efterspurgte dynamik, som kan udfordre den formaliserede og forudsigelige offentlige velfærd. 
spørgsmål om at sikre, at samarbejdet hviler på en veldefineret forventningsafstemning, der kan sikre en klar rollefordeling mellem kommunens professionelle og de frivillige. I stedet bliver ledelse til et spørgsmål om at skabe den fornødne plads til, at de professionelle og de frivillige kan udvikle en undersøgende og eksperimenterende tilgang til, hvordan de skal finde deres roller i forhold til hinanden. Ledelsens opgave er herudover at stå klar til at gribe de muligheder, der opstår i denne afsøgende proces, når de finder, at der opstår noget, som er værd at arbejde videre med, og som man gerne vil skabe mere stabile strukturer omkring.

Vi ser således, at en række kommuner vælger at gå en helt anden vej end den, de mange toneangivende aktører på området anbefaler. Disse kommuner lægger mere vægt på, at det er værdier som ligeværdighed, åbenhed og fleksibilitet, som er styrende for samarbejdet, end regler for en klar arbejdsdeling. Lad os se nærmere på, hvad der karakteriserer en sådan samarbejdsform.

\section{Samskabelse som alternativ til det regelbaserede samarbejde}

Hvis man skal give en samlet betegnelse for de eksperimenter, som Ringkøbing-Skjern Kommune blot er et blandt mange eksempler på, er begrebet samskabelse måske det mest dækkende (Tortzen, 2019). Idéen om samskabelse bygger netop på den forestilling, at samarbejde ikke er noget, der kan defineres ovenfra. I stedet udfordrer begrebet den forestilling, at ledelse af samarbejde mellem den frivillige verden og det offentlige skal "være baseret på en tydelig ansvarsfordeling" (Tortzen, 2019, s. 55). Traditionelle grænser bliver her set som en barriere for udvikling og innovation. Resultatet er, at ethvert forsøg på at formulere klare grænser mellem de professionelle og de frivillige bliver iagttaget som en forhindring for at etablere samarbejdet på idéen om samskabelse. I stedet insisteres på, at samskabelse handler om, at man netop ikke følger en standard for samarbejde, og at man ikke lader strukturer stå i vejen for, at parterne hele tiden kan undersøge, hvordan man sammen kan udvikle velfærden. Værdier som fleksibilitet, nysgerrighed og åbenhed fremhæves på bekostning af regler, og det måles blandt andet ved, i hvilken udstrækning man ude i praksis evner at udvikle nye måder at udvikle velfærden på (Lauritzen, 2019).

Aktørerne har af disse grunde brug for gode relationelle kompetencer, da de ofte vil befinde sig i komplekse situationer uden en klar magtstruktur, og hvor de indbyrdes roller konstant er til forhandling (Tuurnas, 2016, 2020). Vi genkender her den tidligere forsknings påpegning af, at grænser snarere er noget, der bliver til i nuet, og ikke noget, der kan fastlægges på forhånd en gang for alle. I stedet iagttages succesfulde samskabelsesprojekter som nogle, der overskrider traditionelle grænser ved at tillade eller ligefrem invitere de frivillige ind på områder, der tidligere var de professionelles domæne.

Tuurnas demonstrerer i sit arbejde, hvordan netop overskridelser af grænser mellem professionelle og frivillige roller kan være nødvendige for, at et samskabelsesprojekt kan få succes. 
I samskabelse gøres der op med forestillingen om, at samarbejdet foregår inden for en hierarkisk organisering, hvor præmisserne for samarbejdet bliver defineret $\mathrm{i}$ toppen og implementeret i bunden. Der lægges i stedet op til et ligeværdigt og gensidigt anerkendende samarbejde, hvor aktørerne sammen udvikler en undersøgende og eksperimenterende tilgang til samarbejdet. Dette kræver blandt andet, at samarbejdet overlader et stort ansvar til de forskellige aktører, således at de har frihed til at formulere og anvende deres ressourcer på en sådan måde, at det på sigt "vil gå op i en højere enhed og skabe nytænkende løsninger" (Tortzen, 2019, s. 181).
I samskabelse handler det derfor ikke om, at de frivillige skal indpasse sig i en allerede på forhånd aftalt struktur (regler), men at de i stedet får plads til at udfolde deres anderledeshed og deres evne til at udfordre enhver orden og stabilitet (værdier). Det handler derfor om, at kommunen forsøger at skabe en kultur, der ikke længere refererer til en given struktur, en stabil orden, hvor der er klare grænser mellem de professionelles og de frivilliges opgave- og ansvarsområder.

Både de professionelle og de frivillige opfordres derimod til at deltage i en kreativ proces, hvor begge parter anspores til at overskride tidligere tiders etablerede grænser for deres samarbejde. Ledelsen håber således, at de gennem opbygningen af en sådan kultur kan få de involverede aktører til at tænke udover, hvad der traditionelt forventes af dem. På denne måde forsøger man konstant at fastholde usikkerhed og åbenhed, så aktørerne er villige til løbende at eksperimentere med det allerede givne, så nye muligheder kan dukke op i forhold til, hvordan samarbejdet og velfærdsproduktionen skal finde sted. Uforudsigelighed er netop noget, der efterstræbes, idet man forsøget at undgå, at den måde tingene gøres på her og nu pludselig skal stivne til i en forudsigelig struktur, som begrænser aktørerne mulighed for at tænke ud af boksen og finde nye måder at gøre tingene på.

Hvis vi forstår politik, som der hvor grænserne fastlægges, så er det politiske pludselig noget, der finder sted helt lokalt. Det betyder også, at når grænserne ikke længere sættes af de kommunale politikkere, men derimod sættes på spil i de konkrete samarbejdsformer, flytter det politiske med. Det betyder, at de traditionelle politikere også må forstå, at deres rolle som politikere er forandret. De må således formulere en politik, der forstår sig på, at netop spørgsmålet om grænser, roller og personer er noget, der bliver sat politisk på spil i de nye samarbejdsformer (for en længere diskussion af dette se Andersen \& Pors, 2014). De kommunale politikkere må erkende, at selvom de sidder øverst i det formelle beslutningshierarki, så er det ikke op til dem at afgøre, hvordan grænserne skal fastsættes, men dem der snarere skal skabe de nødvendige betingelser for, at de netop kan sættes på spil lokalt. Politikerne må således have blik for den politik, der netop føres ude de i de forskellige velfærdsinstitutioner, fordi det er lige præcis her, samarbejdet sætter de professionelles og frivilliges autonomi på spil.

Det politiske, forstået som der, hvor rollerne og opgaverne bliver defineret, finder således sted på et andet niveau, end der hvor CSFA, KL og FOA argumenterer for, at det skal finde sted. Mens disse aktører tager udgangspunkt $\mathrm{i}$, at der eksisterer en bureaukratisk og hierarkisk struktur, hvor man på forhånd kan beslutte en klar rolle- og opgavefordeling mellem de 
frivillige og professionelle, og hvor ledelsens opgave herefter bliver at sørge for, at disse bliver implementeret, trækker idéen om samskabelse på en horisontal tilgang til spørgsmålet om det gode samarbejde. Her bedrives det politiske ude i de yderste led, hvor de frivillige og de professionelle yder deres omsorg på hverdagens egne dynamiske betingelser. Her er roller og opgaver noget, der bliver til fra neden i et dynamisk samspil, hvor de forskellige aktører konstant udfordrer hinandens roller og opgaver.

\section{Fordele og ulemper ved de to samarbejdsmodeller}

Denne artikel skal ikke afgøre, om den ene eller den anden forståelse af det "gode samarbejde" er bedre end den anden. Alle modeller for samarbejde indeholder udfordringer. Begge modeller indeholder således deres egne fordele og ulemper. Den hierarkiske tilgang, hvor det politiske eksisterer i toppen, skaber tryghed og vished hos alle aktører - hos de professionelle, de frivillige og dem, som indsatsen retter sig imod. Det er tilfældet, fordi alle på forhånd ved, hvem der gør hvad og hvornår. Der er således i princippet ingen tvivl om, hvor grænserne går for den professionelle og den frivillige indsats. Men den hierarkiske organisering fastholder også aktørerne i nogle prædefinerede roller, som let bliver ufleksible, og som i sidste ende kan underminere muligheden for udvikling, dynamik og den innovation, som det nationale frivilligheds charter påpeger, er nødvendig for udviklingen af vores velfærdssamfund. I stedet for at ledelse handler om at skabe muligheder, bliver ledelse let til et spørgsmål om at sikre klare aftaler og deres overholdelse. Enhver afvigelse fra det aftalte bliver dermed til noget, der kalder på sanktioner fra ledelsens side.

\section{Ved at behandle de frivillige som nogle, der skal indtage en bestemt plads i en på forhånd defineret struktur, forhindrer man den enkelte frivillige i at finde sin egen måde at være frivillig på, hvilket let medfører, at de frivillige forsøger at blive succesfulde på de professionelles betingelser, som de netop skulle udgøre et alternativ til.}

Samskabelsesprojekterne fordrer derimod en helt anden tilgang til, hvordan samarbejdet skal organiseres. Her bliver klare strukturer for samarbejdet tværtimod set som noget, der står i vejen for udvikling og innovation. I stedet lægges der vægt på, at roller og opgaver er noget der skal udvikles fra neden, og grænser er noget, der skal udfordres og muligvis overskrides. Der er ingen autoritet, der kan formulere målsætninger eller legitimere strategier for deres indløsning. I stedet bliver velfærden et resultat af en konstant bevægelse, af mere eller mindre løse koblinger af enkelt stående episoder og situationer. Processen bliver til i et væld af forskellige praksisser, uden klar sammenhæng og uden tydelig retning. Ingen har autoritet til at afgøre, hvornår noget er godt eller skidt, og om det bidrager til en given strategi for indløsningen af et bestemt mål, alene af den grund, at der ikke eksisterer nogen strategi, andet end at der ikke må være nogen strategi. Samskabelse risikerer dermed at fremstå som en rodet og decentreret form for velfærdsproduktion, der kan vokse i alle retninger, og som konstant er åben for forandringer. Uforudsigelighed, ustabilitet og usikkerhed bliver den nye norm for disse samskabelsesprojekter.

Men selvom idéen om samskabelse hviler på den præmis, at strukturer er noget, der skal undgås, er det jo ikke ensbetydende med, at alle strukturer forsvinder. Snarere er der tale om, at der opstår en splittet samtidighed af både struktur og mangel på samme, som producerer sine egne former 
for ambivalens, fordi det kan være vanskeligt i de enkelte situationer at vide, hvornår man skal vælge at referere til en struktur, og hvornår man skal understrege situationens karakter af fuldstændig åbenhed. Denne ambivalens deler samskabelsesprojekterne med den hierarkiske forståelse af det gode samarbejde, for også her eksisterer jo dynamiske processer, som følge af at hverdagens intensitet og kompleksitet ikke lader sig inddæmme af de konkrete aftaler, man har nedfældet om dem på forhånd. Også her vil man stå i situationer, hvor man som ledelse skal afgøre, om man skal insistere på strukturen eller lade hverdagens uforudsigelighed komme til sin ret.

\section{Konklusion}

Nogle gange er den mest simple måde at håndtere det modsætningsfyldte forhold mellem værdier og regler på at vælge at gøre den ene af dem til selve normen for samarbejdet. Således vælger det regelbaserede samarbejde at fundere samarbejdet på formuleringen af klare regler, mens samskabelsesprojekterne ophøjer værdierne fleksibilitet og ligeværdighed som rettesnor for samarbejdet. Mens det formaliserede samarbejde undergraver værdien af de frivilliges autonomi, mangler samskabelsesprojekter evnen til at integrere de frivilliges autonomi i mere varige og solidariske former for velfærd. Begge modeller har således deres fordele og ulemper, men vigtigt at bemærke er, at de gennem deres ensidige fokusering på enten regler eller værdier overser, at både regler og værdier er lige nødvendige i ethvert samarbejde med frivillige.

Det, som mellemlederne var så dygtige til i BBBS, var at de netop anerkendte, at dette var betingelserne for at lede frivillige. I stedet for at ignorere modsætningerne havde de skabt en kultur, hvor man kollektivt diskuterede de konkrete dilemmaer, som modsætningerne resulterede i, og de forskellige svar, der var mulige. Ved at fremme evnen til at have blik for det modsætningsfyldte i organisationens værdier og regler, havde de skabt en åben kultur, hvor det at stille spørgsmål og være i tvivl var legitimt. Og ved at anerkende, at der ofte ikke eksisterer et "rigtigt svar" på en given situation, men at der altid er flere scenarier, der byder sig til, og som man sammen i ledelsesteamet kunne udfolde, anerkendte mellemlederne kompleksiteten $\mathrm{i}$ deres funktion som ledere.

Det var med andre ord som om, at mellemlederne i BBBS havde udviklet en grundlæggende forståelse for, at modsætningen mellem værdier og regler ganske enkelt udgør den grundlæggende præmis for ledelse af frivillige. Og at der ikke findes nogen universel løsning på, hvordan forholdet mellem værdier og regler skal være. Den præmis vil derimod altid bringe ledelsen ud i nye situationer og presse den til nytænkning. I stedet for at behandle det som et problem, der enten skal ignoreres eller løses, er det vigtigt, at ledelsen har blik for, hvordan regler og værdier er på spil i den konkrete kontekst. Der er således stor forskel på, hvordan modsætningerne viser sig - taler vi for eksempel om frivillige patientstøtter på et hospital eller frivillige til vedligeholdelsen af en park. Pointen er imidlertid, at uanset konteksten er det vigtigt, at organisationen udvikler sine lederes evne til at have blik og forståelse for, hvordan værdier og regler er på spil i de mange konkrete situationer, som samarbejdet mellem de professionelle og de frivillige giver anledning til. Det er desuden vigtigt, at organisationen arbejder for at 
skabe en kultur, hvor det er muligt for lederne, åbent at diskutere deres iagttagelser med hinanden og sammen udfolde forskellige scenarier for, hvad man kan gøre - for så at træffe en kollektiv beslutning. Hermed er der skabt mulighed for, dels at skabe en kollektiv læring i organisationen om, hvordan modsætningerne mellem regler og værdier viser sig i netop deres kontekst for samarbejdet med de frivillige. Dels at udvikle en kollektiv læring om, hvad der synes at virke, og hvilke nye udfordringer det kan give anledning til.
Det er med andre ord min påstand, at man i stedet for at bruge kræfter på at benægte modsætningerne mellem regler og værdier og insistere på at skabe rationelle og effektive beslutningsstrukturer, der kan usynliggøre eksistensen af hverdagens mange dilemmaer og paradokser, kommer længere i udviklingen af sin organisation, hvis man udvikler ledere, der på alle niveauer er i stand til at forstå og acceptere, at ledelse af frivillige foregår på modsætningsfyldte præmisser. Dette kan nok producere tvivl, usikkerhed og frustrationer, men det kan samtidig også give anledning til refleksion, kreativitet og udvikling, fordi der netop aldrig er en rigtig model for samarbejdet at falde tilbage på.

Disse overvejelser ville jeg gerne have haft mulighed for at diskutere med ledelsen af BBBS i Chicago den sommerdag i juni. Jeg kom desværre ikke så langt i mit oplæg. I stedet blev jeg afbrudt, da jeg indledningsvis skitserede forskellige situationer, hvor deres mellemledere var nødt til at navigere mellem organisationens mange regler og værdier. De to ledere mente jeg tog fejl og erklærede, at der bestemt ingen modsætninger var mellem BBBS regler og dens værdier. Her begyndte så en ordveksling, som hurtigt udviklede sig til, at jeg forsøgte at argumentere for eksistensen af modsætninger, mens de to ledere på skift argumenterede for, at der ingen var. Da lederne begyndte at føle, at de pludselig skulle forsvare deres måde at gøre tingene på, at de på en eller anden måde var på anklagebænken, hvilket på ingen måde havde været min hensigt, afsluttede den øverste leder vores møde og sagde kort, men bestemt, at nu var tiden gået. Jeg nåede ikke at fremstamme, at mødet kun var halvvejs henne, før de to kvinder, næsten synkront havde rejst sig, som om ingen af dem ville risikere at skulle blive efterladt alene med mig i lokalet, og gav mig køligt hånden og sagde tak for i dag. Før jeg havde genfundet fatningen, var jeg ude af lokalet og henne ved receptionen, hvor receptionisten havde været så venlig allerede at have trykket på elevatorknappen til "Ground Floor".

Siden jeg overrasket igen stod på den trafikerede gade, har jeg tænkt meget over, hvordan det kunne gå så galt. Mine indledende iagttagelser af modsætningerne mellem BBBS' værdier og regler var blevet mødt med blank afvisning: Kontrakten, de frivillige underskrev, gjaldt jo kun et år; de ansatte var professionelle og havde mange års erfaringer, hvorfor de vidste, hvordan de skulle få "enderne til at mødes". I nogle tilfælde var det ok at overskride en regel, men skete det regelmæssigt, skred organisationen ind. Mine modspørgsmål om, hvordan man som organisation kunne afgøre, at på præcist årsdagen for relationen var der ikke behov for reglerne mere, eller hvordan man kunne afgøre, hvornår en regel var blevet brudt "for mange gange", blev ikke besvaret. I stedet havde mødet udviklet sig til en uheldig krig på ord, og jeg var nok blevet lidt for engageret i min udfordring af ledernes opfattelse af, at der ingen "dilemmaer" eller "modsætninger" var i ledelsen af deres frivillige. Jeg fremstod pludselig og mod min vilje som en muldvarp, hvis eneste ønske var at "afsløre" BBBS' modsætningsfyldte arbejde med udsatte børn. 
Noget af forklaringen på, at mødet kom så galt afsted, kan givetvis findes i de forskelle, der ofte er blevet fremhævet mellem de ledelsesforståelser, der eksisterer på tværs af Atlanten. Mens vi i Europa, og i særdeleshed i Skandinavien, ofte udviser en vis skeptisk attitude, når det gælder tiltroen til ledelsens muligheder for at rationalisere og kontrollere, så hersker der i USA i højere grad en modsvarende stor tiltro til, at der ikke findes nogen situation, der er så kompleks, at den ikke kan bringes under ledelsens kontrol (Farson, 1996, s. 15; Mowles, 2015). Mine mange beskrivelser af de uklare og modsætningsfyldte situationer, som deres mellemledere ofte befandt sig i, var for topledelsen et tegn på, at noget var galt, og det havde virket provokerende.

I stedet for at falde for mit slet skjulte forsøg på at smigre dem med min beundring for deres mellemlederes evne til at navigere og improvisere i en modsætningsfyldt hverdag, var de blevet stødt af min beskrivelse af deres organisation som en, der ikke havde udviklet klare og sammenhængende regler og værdier, der kunne bruges til at effektivisere organisationens hverdag. De var optaget af optimering af arbejdsprocesser og fandt, at mine beskrivelser var eksempler på, at dette ikke var lykkedes, og at deres ledelse med andre ord havde fejlet og efterladt deres mellemledere i en kaotisk hverdag uden klare retningslinjer, som det netop var deres ansvar, som topledelse at sikre tilstedeværelsen af.

Min pointe er imidlertid, at en professionel ledelse ikke skal genkendes på dens evne til at strømline regler og værdier, når det gælder ledelse af frivillige. Tværtimod skal den genkendes på dens evne til at undgå at blive paralyseret af den indsigt, at regler og værdier er umulige at forene, men at det ikke desto mindre er vigtigt hele tiden at forsøge at gøre det umulige muligt. Måske fordi den amerikanske psykolog Richard Farson så rigtigt, da han skrev: "Tabte sager er ofte dem, der er mest værd at kæmpe for, fordi de repræsenterer det vigtigste, det mest humane... tabte sager kan ikke vindes, men fordi de er så vigtige for os, må vi ikke desto mindre fortsætte med at forsøge" (Farson, 1996, s. 163, min oversættelse). 


\section{Litteratur}

Blix, B. \& Hamran, T. (2017). 'When the saints go marching in': Constructions of senior volunteering in Norwegian government white papers, and in Norwegian senior volunteers' and healthcare professionals' stories. Ageing and Society, 38(7), 1-30. https://doi.org/10.1017/ s0144686x17000046

Andersen, N. Å., \& Pors, J. G. (2014). Velfærdsledelse: Mellem styring og potentialisering. Hans Reitzels Forlag.

van Bochove, M., Tonkens, E, Verplanke, L. \& Roggeveen, S. (2018) Reconstructing the professional domain: Boundary work of professionals and volunteers in the context of social service reform. Current Sociology, 66(3), 392-411. https://doi.org/10.1177/0011392116677300

Center for frivilligt socialt arbejde. (2020). Sådan udarbejder I en samarbejdsaftale. https://frivillighed.dk/guides/saadan-udarbejder-i-en-samarbejdsaftale

Frivilligheds chartret. (2013). Charter for samspil mellem den frivillige verden og det offentlige. https://www.ft.dk/samling/20121/almdel/sou/bilag/292/1267207.pdf

Farson, R. (1996). Management of the Absurd - Paradoxes in Leadership. New York: Simon \& Schuster.

Henriksen, L. S. (1996). Lokal frivillig organisering i nye omgivelser. Alfuff.

Hjære, M. \& Jørgensen, H. E. D. (2017). Tal om kommuner og frivillighed: Analyse af kommunernes engagement og samarbejde på det frivillige velfærdsområde. En del af Frivilligrapporten 2016-2018. Odense: Center for Frivilligt Socialt Arbejde.

https://doi.org/10.22439/dansoc.v26i2.5048

Cour, A. L. (2014). Frivillighedens logik og dens politik. Nyt fra Samfundsvidenskaberne.

Cour, A. L. (2019). The management quest for authentic relationships in voluntary social care. Journal of Civil Society, 15(1), 1-17.

Lauritzen, G. D. (2019). Looking beyond formal organization: How public managers organize voluntary work by adapting to deviance. Systems Research and Behavioral Science, 37(3), 467-481. https://doi.org/10.1002/sres.2686

Luhmann, N. (2000a). Organization and Decision. Cambridge: Cambridge University Press.

Luhmann, N. (2000b). Sociale systemer - Grundrids til en almen teori. København: Hans Reitzels Forlag. https://doi.org/10.7146/politica.v32i4.68418

Merrel, J. (2000). Ambiguity: Exploring the complexity of roles and boundaries when working with volunteers in well woman clinics. Social Science \& Medicine, 51(1), 93-102. https://doi.org/10.1016/s0277-9536(99)00442-6

Mowles, C. (2015). Managing in uncertainty - Complexity and the paradoxes of everyday organizational life. New York: Routledge. https://doi.org/10.4324/97813157308999

Mowles, C., Stacey, R., \& Griffin, D. (2008). What contribution can insights from the complexity sciences make to the theory and practice of development management?. Journal of International Development: The Journal of the Development Studies Association, 20(6), 804-820. https://doi.org/10.1002/jid.1497 
Overgaard, C. (2015). The Boundaries of care work: a comparative study of professionals and volunteers in Denmark and Australia. Health \& Social Care in the Community, 23(4), 380-388. https://doi.org/10.1111/hsc.12154

Overgaard, C. (2019). Rethinking volunteering as a form of unpaid work. Nonprofit and Voluntary Sector Quaterly, 48(1), 128-145. https://doi.org/10.1177/0899764018809419

Schwartz, S. H. (1992). Universals in the content and structure of values: Theory and empirical tests in 20 countries. I: M. Zanna (Red.), Advances in experimental social psychology, Vol. 25, (pp. 1-65). New York: Academic Press. https://doi.org/10.1016/s0065-2601(08)60281-6

Social- og Indenrigsministeriet. (2020). https://sim.dk/find/?query=charter\%20for\%20 samspil\%20mellem\%20den\%20frivillige\%20\&template=All

Skinner, M. S., Lorentzen, H., Tingvold, L., Sortland, O., Andfossen, N. B., \& Jegermalm, M. (2020). Volunteers and Informal Caregivers' Contributions and Collaboration with Formal Caregivers in Norwegian Long-term Care. Journal of aging \& social policy, 1-26. https://doi.org/10.1080/08959420.2020.1745988

Striib, M. (2019). Linedans: Når frivillige og medarbejdere tager en svingom på velfærdsstatens travle gulv. Tidsskrift for Arbejdsliv, 21(4), 79-82.

Thyssen, O. (2007). Værdiledelse. Gyldendal A/S.

Tortzen, A. (2019). Samskabelse af velfærd - muligheder og faldgrupper. Hans Reitzels Forlag. Tuurnas, S. (2016). The Professional side of Co-production. Tampere: University of Tampere Tuurnas, S. (2020). Skilling and motivating staff for co-production. I: The Palgrave Handbook of Co-Production of Public Services and Outcomes (pp. 491-506). Palgrave Macmillan, Cham. https://doi.org/10.1007/978-3-030-53705-0_25

Verhoeven, I., \& van Bochove, M. (2018). Moving Away, Toward and Against: How Front-line Workers Cope with Substitution by Volunteers in Dutch Care and Welfare Services. Journal of Social Policy, 47(4), 783-801. https://doi.org/10.1017/s0047279418000119

Ziegler, M. \& Adelskov, T. (2019). Vi er fælles om fremtidens velfærd. Tidsskrift for Arbejdsliv, 21(4), 76-79. 